\title{
Determination of the spatial and temporal dynamics of water erosion development using GIS technologies
}

\author{
Faik Safiollin ${ }^{1, *}$, Mikhail Panasyuk ${ }^{2}$, Svetlana Sochneva ${ }^{1}$, and Nikolai Trofimov ${ }^{1}$ \\ ${ }^{1}$ Kazan State Agrarian University, Kazan, 420015, Russia \\ ${ }^{2}$ Kazan Federal University, Kazan, 420008, Russia
}

\begin{abstract}
Currently, there are 0.21 hectares of arable land for every inhabitant of the planet. According to the UN forecast, the availability of arable land in the future will decrease to 0.14 ha/person not only due to population growth, but also due to land allotment for the construction of settlements, industrial facilities, hydroelectric power stations, mining and, most importantly, for strengthening erosion processes of anthropogenic nature. So, over the past 30 years, 58 hectares of arable land of the Bolsheelovskoye JV of the Elabuga municipal district of the Republic of Tatarstan has been withdrawn from agricultural circulation. In addition, a comparative assessment of the initial soil cartogram with a map compiled 30 years later using the geographic information system showed a 2-fold increasing area of medium washed-out soils and the transition of 100 hectares of unwashed-out arable land to the category of slightly washed. Based on the research results, we developed a set of anti-erosion measures, including the planting of stock-regulating and field-protecting forest strips, strip lane placement of crops and increasing soil fertility based on the biologization of farming.
\end{abstract}

\section{Introduction}

The word "erosion" has a Latin origin and means "to erode", it occurs under the influence of wind force (lower and upper wind erosion), rainfall and accelerated snowmelt (surface and linear ravine water erosion), energy-saturated agricultural machinery (technical erosion), irrigation water (irrigation erosion), etc.

Destruction of the fertile soil layer depends on the development of the productive forces of society, the higher the power ratio, the stronger the human impact on the soil is manifested [1].

On the other hand, soil and climatic conditions have a great influence. In farms located in the steppe zone, the area of arable land and soil fertility decrease due to wind, and in the forest and forest-steppe zones this occurs due to water erosion [2].

So, according to many scientists $[3,4]$ in the Russian Federation annually 150 thousand hectares of arable land turn into ravines, and deserts come at a speed of 50 thousand hectares/year.

Therefore, the development of methods for protecting soils from erosion considering the soil and climatic conditions of their location region is an urgent problem of the modern agro-industrial complex of both the Russian Federation and the Republic of Tatarstan.

In this regard, the aim of the research was to develop highly effective anti-erosion measures based on the analysis of the spatial and temporal development of the ravine-beam network using the potential capabilities of GIS technologies.

\section{Methods and research techniques}

Bolsheelovskoye settlement is located on the left bank of the Vyatka River on the Elabuga-Predkamskaya Upland. The land use area is 5,245.2 hectares, including 3325 hectares of arable land, 732 hectares of hayfields and pastures. High ploughing of agricultural land (75\%) and the presence of slopes with a steepness of more than $5^{\circ}$ along with the use of intensive technology of crop cultivation have an amplifying effect on the formation of ravine-beam network.

To conduct spatial and temporal monitoring of the dynamics of the development of water erosion, we used a soil cartogram compiled at the end of the 20th century, which was scanned and digitized using the Easy Trace GIS.

After 30 years, we carried out an adjustment of the soil cartogram using the Panorama geographic information system. Then, using the DigitMap map editor, we created areal objects that were exported to MapInfo GIS. It resulted in the structure of the spatial database for a comparative assessment of the ravine system development on the territory of the research object [5].

\section{Results and discussion}

Before analyzing research results, we should note the importance of determining the area of land by the degree

\footnotetext{
$\bar{*}$ Corresponding author: dusai@mail.ru
} 
of washout, since the dynamics of the development of water erosion depends on this indicator [6]. For example, a paper digitized cartogram of the end of the last century (1989) shows the prevalence of slightly and medium washed-out soils in the territory of the object of study (Fig. 1).
Slightly washed-out soils accounted for $25-28 \%$ of the arable land, while medium washed-out soils occupied $30-35 \%$. On the original map, there were 3 points of heavy washed-out soil, but there was no very heavy washed-out soil. After 30 years, the area of slightly washed-out soils increased by 100 ha (Fig. 2).

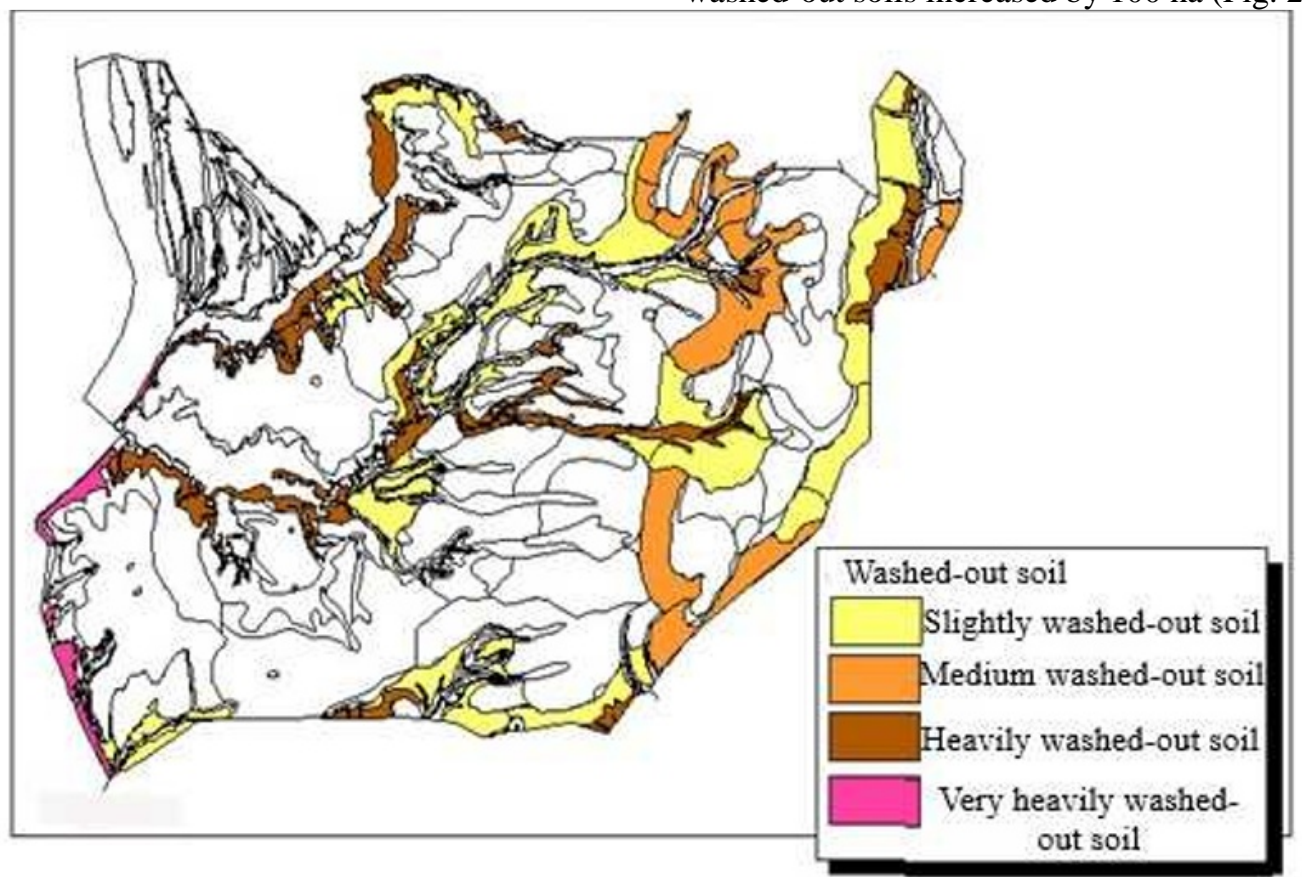

Fig.1. The original map of soil erosion of the Bolsheelovskoye settlement of the Elabuga region (1989)

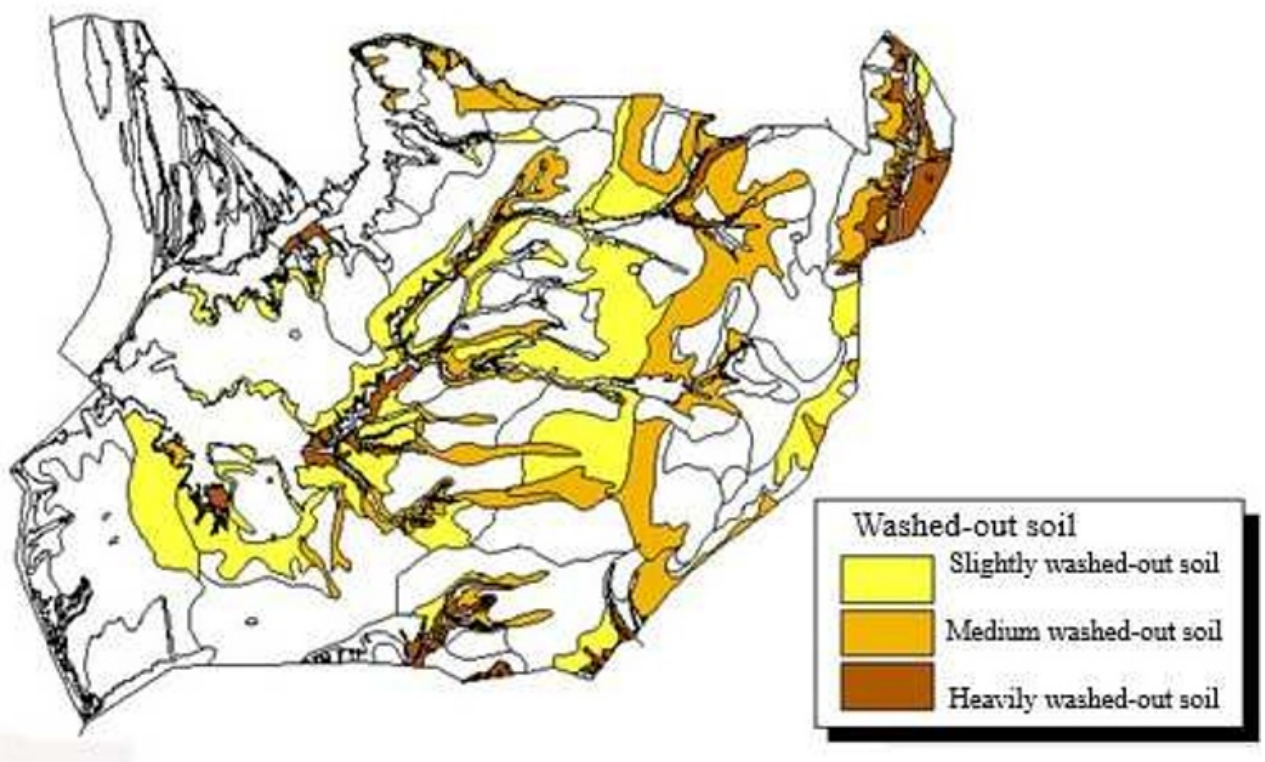

Fig. 2. The modern map of soil erosion of the Bolsheelovskoye settlement of the Elabuga region (2019)

A more detailed analysis of 2 maps shows that this process occurred due to the transition of unwashed-out soils to the category of slightly washed-out soils.

We should especially note the 2-fold increase of medium washed-out soils over the past 30 years since the intensification of agricultural production, combined with a significant decrease in the volume of organic fertilizers, the use of green manure, and the reduction of perennial grasses, caused increased water erosion. We will consider the following example to confirm this point of view. On the land use territory of the Bolsheelovskoye settlement, there are two types of light grey soils: light grey forest and light grey podzolic soils, three types of grey forest soils: sod-medium-podzolic, sod-mediumpodzolic surface-gley and sod-carbonate typical soils. Floodplain soils have four types: floodplain swamp silt- 
gley, floodplain soddy coarse-layered, floodplain soddy thin-layered, floodplain soddy granular (Fig. 3).

Among the above three varieties, light grey soils are most susceptible to flushing, a change in their boundaries clearly confirms this (Fig. 4).

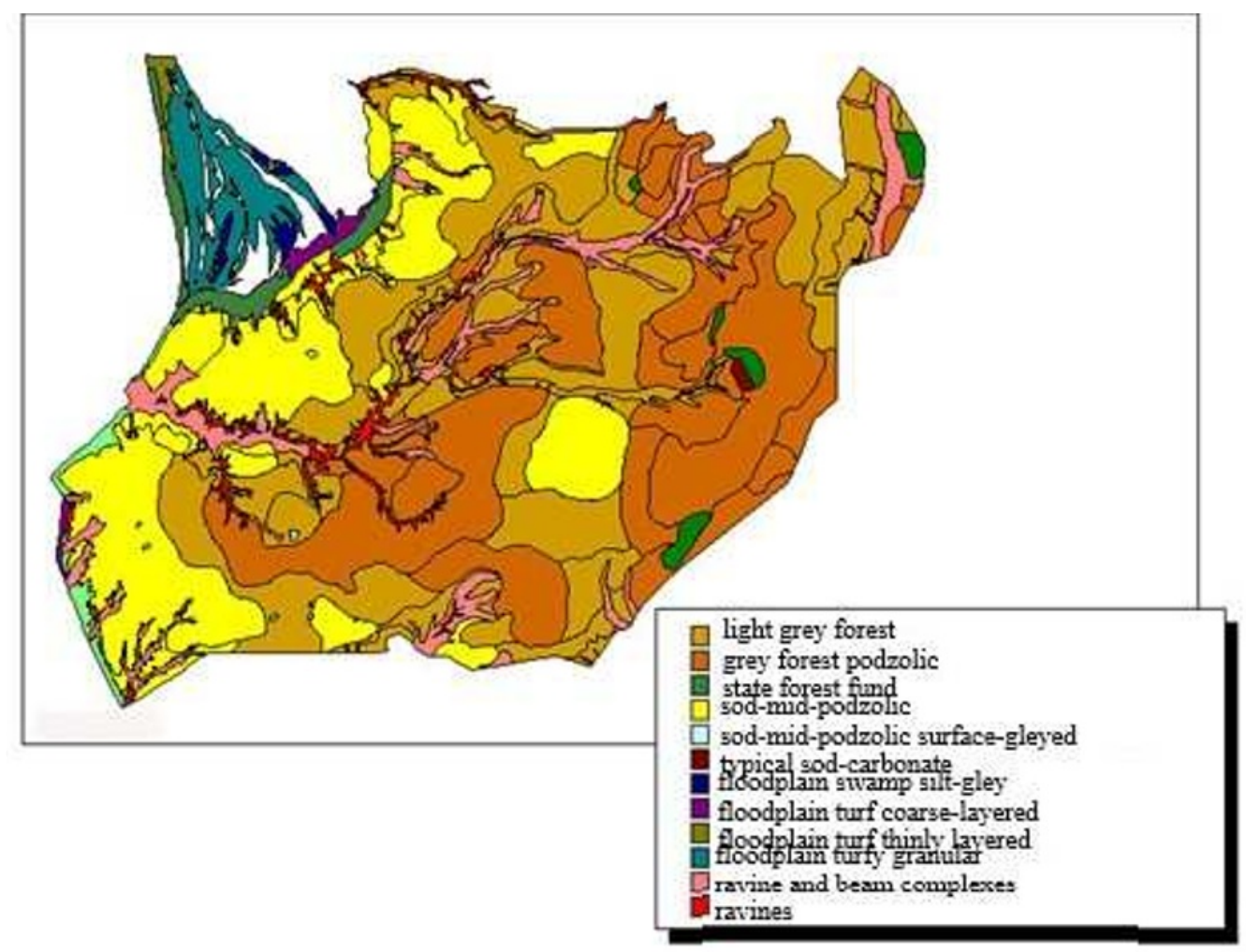

Fig. 3. The soil map of the Bolsheelovskoye settlement of Elabuga district

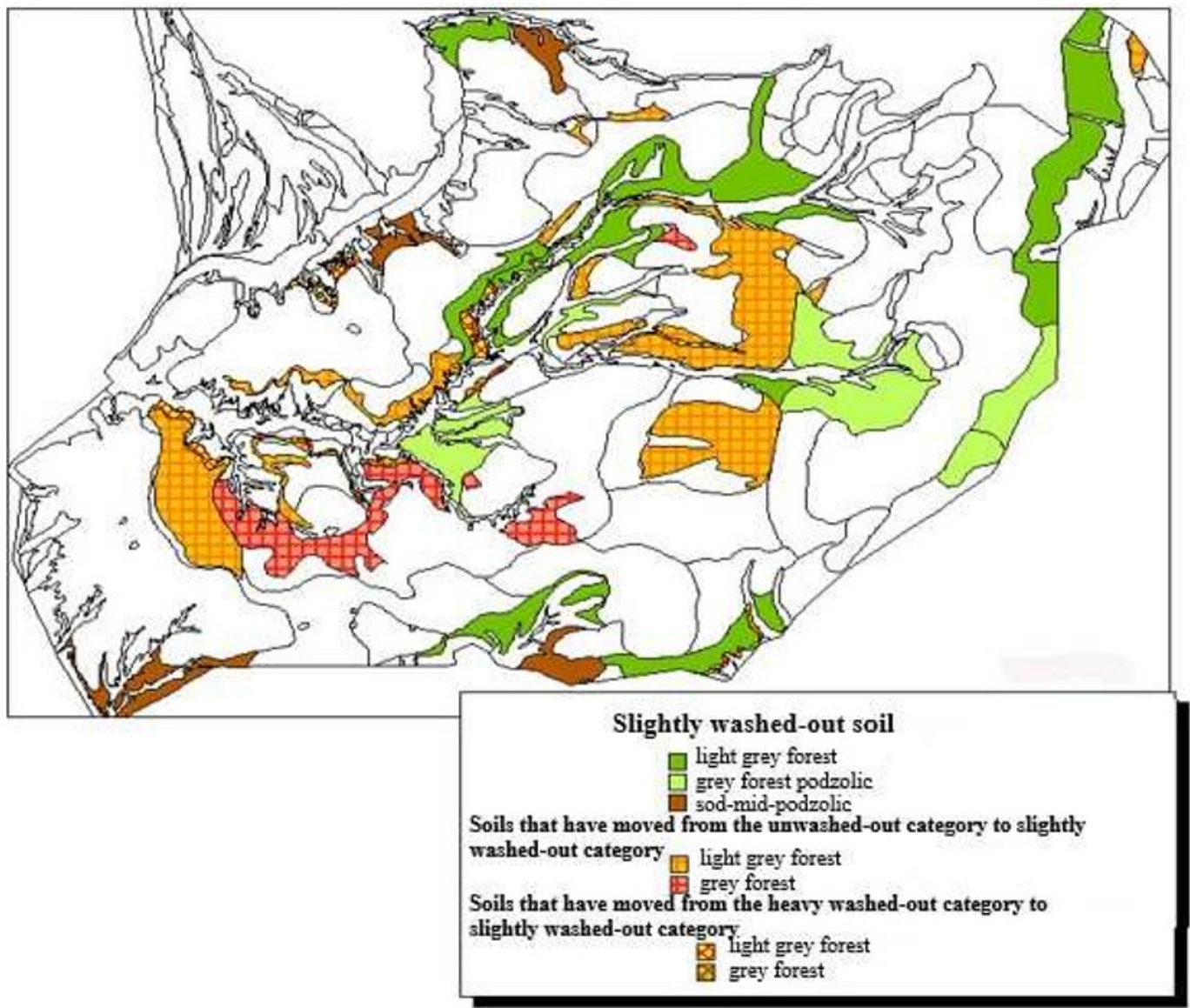

Fig. 4. Changing the boundaries of slightly washed-out soils considering soil types 
Consequently, there is a close correlation between fertility and soil degradation: the lower the soil fertility, the more susceptible it is to water erosion and the formation of a ravine-beam network. As a result, 58 hectares of arable land were withdrawn from agricultural circulation [7].

An objective assessment of the agroecosystem stability to water erosion, as a rule, requires the calculation of territorial roughness of the farm land use, which we determine using the following formula:

$$
R_{T}=\frac{L}{S} \text {, where }
$$

$\mathrm{R}_{\mathrm{T}}$ is the coefficient of territorial roughness, $\mathrm{L}$ is the total length of ravines and beams, $\mathrm{km}, \mathrm{S}$ is land use area, $\mathrm{km}^{2}$.

The final calculations showed very deplorable results: over 30 years, the territorial roughness of the Bolsheelovskoye settlement increased by $56 \%$ and amounted to 1.75 against 1 on average in the Republic of Tatarstan (Fig. 5).

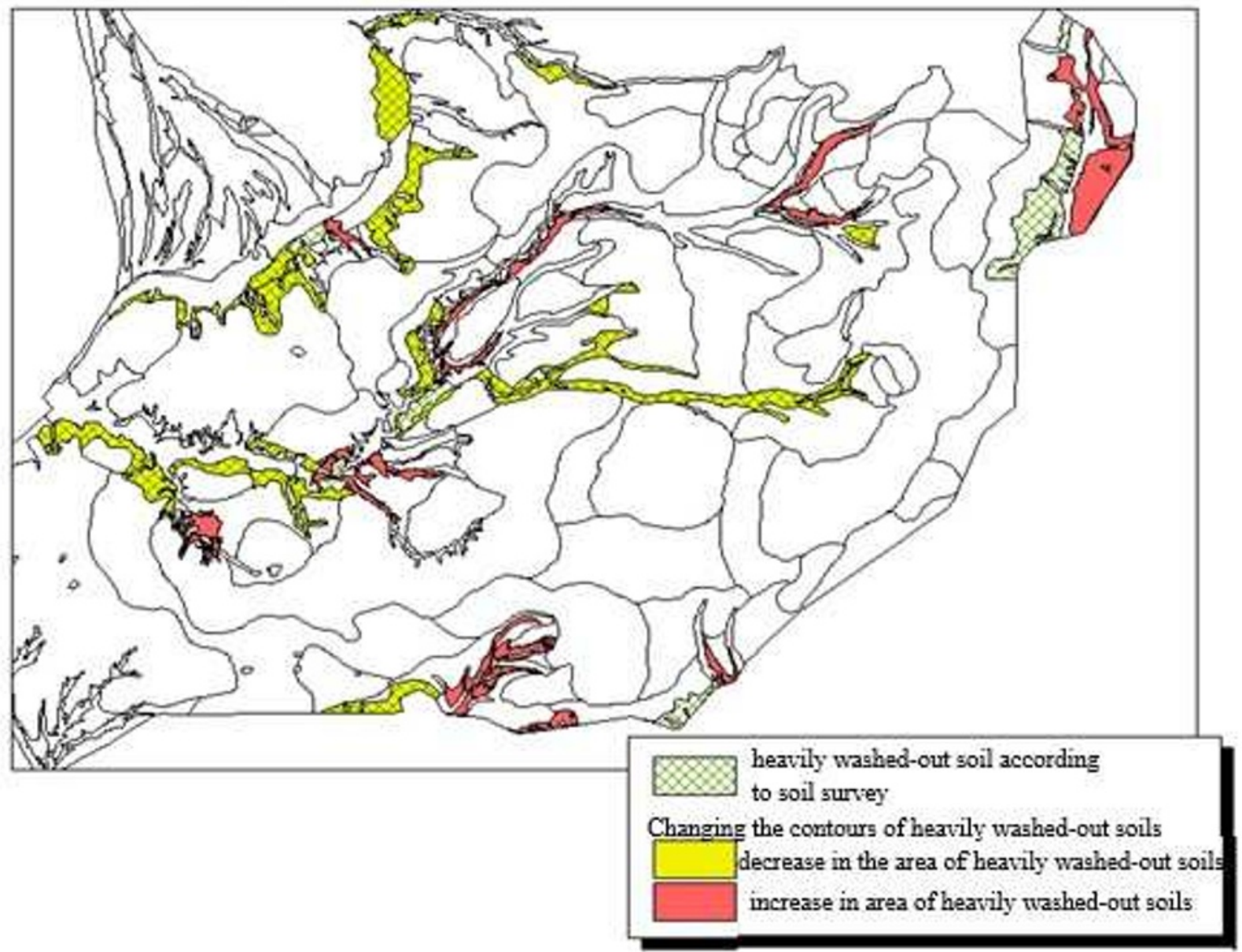

Fig. 5. The current state of the ravine-beam system in the land use Bolsheelovskoye settlement

Most importantly, if we do not take drastic antierosion measures, the top of the ravine continues to grow not only in depth but also in length at a speed of $3 \mathrm{~m} / \mathrm{year}$.

There are 4 stages of ravine development:

Stage 1 - the formation of holes with a depth of 8-10 $\mathrm{cm}$ with accelerated snowmelt. Their elimination requires tillage across the slope, starting with the closure of moisture;

Stage 2 - the formation of a vertex cliff. When processing the soil along the slope, small ravines deepen and peak cliffs form over time, they can be easily eliminated with simple water dividers (Figures 6, 7).

Stage 3 - the growth of the ravine in length and depth. Without control measures, the summit cliff, as mentioned above, grows at a speed of $3 \mathrm{~m} /$ year and this process continues to the watershed area;

Stage 4 - the attenuation of the growth of the primary ravine in length and depth, overgrowing of its herbaceous and tree-shrub vegetation [8-10].

Unfortunately, after attenuation of the growth of the primary ravine, its secondary and subsequent branches form in mass. For this reason, the only salvation is to plant dense and ravine forest lanes of dense construction in a $1 \times 2$ pattern.

The distance between bushes and trees in rows is $1 \mathrm{~m}$ and between rows it is $2 \mathrm{~m}$. At the same time, a number of shrubs alternate with a number of trees. The total width of the forest strip depends on the steepness of the slope and ranges from 6 to $12 \mathrm{~m}$.

In addition to planting forest strips on sloping lands, we need to pay special attention to following agrotechnical measures to combat water erosion $[11,12]$ :

- strip farming: on sloping lands, a strip of cerealleguminous perennial grasses alternates with a strip of 
spring and winter crops;

- agrolandscape placement of crops in space, considering their biological characteristics;

- general biologization of agriculture based on the expansion of the cultivated areas of green crops (white mustard, spring rape, melilot, lupine, etc.), perennial leguminous herbs, chopping and plowing of straw;

- mineral, organic and bacterial fertilizers, trace elements, biological products and growth stimulants;

- purchase of integrated anti-erosion agricultural machines that provide tillage with stubble preservation and many others.

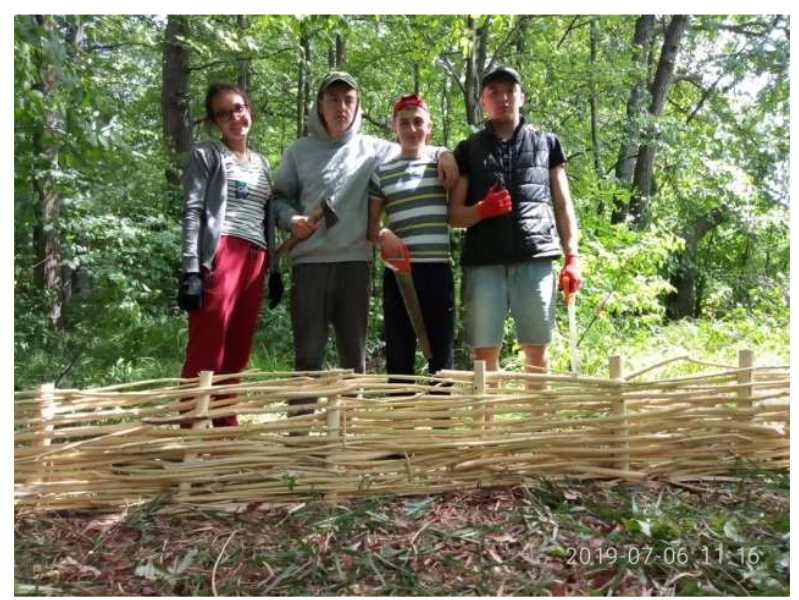

Fig. 6. Students of Kazan State Agrarian University in the practice of engineering the territory

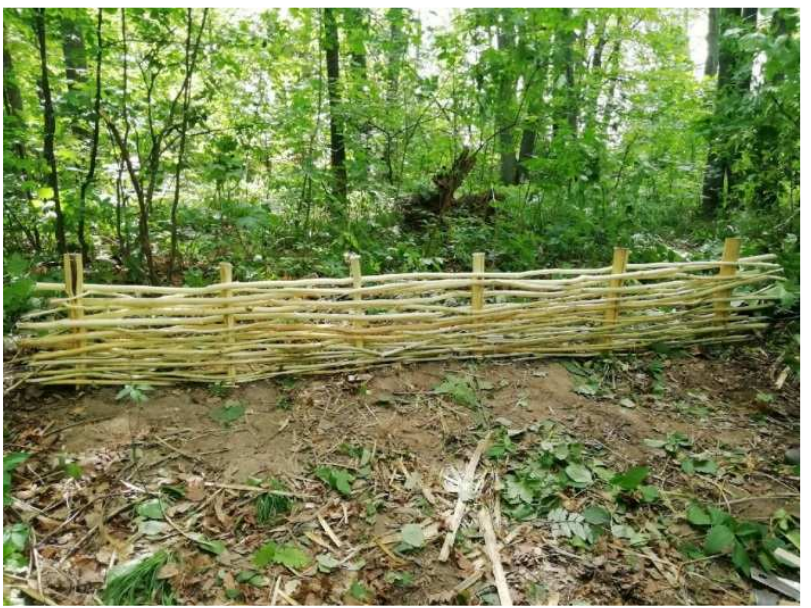

Fig. 7. Water dividers

\section{Conclusion}

Spatial and temporal analysis of the dynamics of the development of water erosion in the land use of Bolsheelovskoye settlement showed an intensification of this process, a significant expansion of the areas of washed-out soils and ravine-beam systems. In this regard, over 30 years, roughness increased to 1.75 against 1 on average in the Republic of Tatarstan.

To reduce the rate of growth of water erosion, we have developed and recommended a set of measures, including agricultural, forestry, hydraulic and biological measures, the introduction of which will ensure sustainable development and a favourable living environment for the population of the Bolsheelovskoye settlement in the Elabuga municipal region of the Republic of Tatarstan.

\section{References}

1. G.A. Demidenko, N.V. Fomina, Ecological bases of nature management: textbook (Krasnoyarsk State Agrarian University, 2014) 88 p.

2. E.N. Volodina, A.D. Tikhonova, Influence of water erosion processes on the physical and chemical properties and humus content of gray forest soils Bulletin of the Nizhny Novgorod State Agricultural Academy, 2(22), 4-8 (2019)

3. Z. M. O. Abbasov, S. Sh. O. Veliyev, Strip cultivation of crops on the slopes, Eurasian Union of Scientists, 1-2(22) (2016) Retrieved from: https://cyberleninka.ru/article/n/polosovoevozdelyvanie-selskohozyaystvennyh-kultur-nasklonah

4. O.V. Makleev, Rapid assessment of erosion-hazardous areas of soil in the Republic of Tatarstan using data from remote sensing of the earth, considering climatic factors, Start in science, 2, 15-24 (2016)

5. I.K. Lurie, A.G. Kosikov, Theory and practice of digital image processing, in: Remote sensing and geographic information systems (Nauchny Mir, Moscow, 2003) $168 \mathrm{p}$.

6. I.I. Karmanov, D.S. Bulgakov, E.A. Shishkonakova, $A$ system for assessing natural and anthropogenic impacts on changing soil fertility in arable land based on a soil-agroclimatic index, Bull. of Soil Institute, 72 (2013) Retrieved from: https://cyberleninka.ru/article/n/sistema-otsenkiprirodno-antropogennyh-vozdeystviy-na-izmenenieplodorodiya-pochv-pahotnyh-zemel-na-osnovepochvenno

7. O.P. Ermolaev, R.A. Medvedeva, E.V. Platoncheva, Methodological approaches to monitoring erosion processes on agricultural lands of the European part of Russia using satellite imagery, Scientific Notes of Kazan University. Series of Natural Sciences, 159, book 4, 668-680 (2017)

8. A.A. Tanasienko, A.F. Putilin, V.S. Artamova, Ecological aspects of erosion processes (Novosibirsk, 1999) $89 \mathrm{p}$.

9. V.M. Ivonin, Overgrowing and stability of ravine slopes, Scientific journal of Russian RRILRP, 2(18) (2015) Retrieved from: https://cyberleninka.ru/article/n/zarastanie-iustoychivost-sklonov-ovragov

10. E.A. Gaevaya, A.E. Mishchenko, I.V. Safonova, The fight against water erosion in crop rotation on sloping lands, Scientific journal of Russian RRILRP, 1 (2012) Retrieved from: https://cyberleninka.ru/article/n/borba-s-vodnoyeroziey-v-sevooborotah-na-sklonovyh-zemlyah

11. R.M. Nizamov, F.N. Safiollin, M.M. Khismatullin, M.I. Giliazov, F.A. Davletov, R.S. Shakirov, 
International Journal of Advanced Biotechnology and Research (IJABR), 10(1), 341-347 (2019)

12. M.M. Khismatullin, M.M. Khismatullin, L.T. Vafina,
F.N. Safiollin, IOP Conference Series: Earth and Environmental Science, 341, 012109 (2019) DOI: 10.1088/1755-1315/341/1/012109 